\title{
Seasonal performance estimation of thin film photovoltaic technology
}

\author{
Akshay Nichinte ${ }^{1, *}$, Vishwesh Vyawahare ${ }^{2, * *}$, and Dhiraj Magare Va** $^{3, * *}$ \\ ${ }^{1,2,3}$ Department of Electronics Engingneering, Ramrao Adik Institute of Technology, Navi Mumbai, India
}

\begin{abstract}
The performance of photovoltaic (PV) module in the environment can be improved by considering the seasonal effects. In this paper, the effect of seasonal variations of Amorphous-Silicon/thin film photovoltaic technology in different seasons has been presented for National Institute of Solar Energy (NISE), Gurgaon site in India. It has been observed that, the estimation efficiency and output power of a-Si technology using module temperature is well match to measured efficiency and output power. This study is mainly very important in India because of the each season's variation effect on different PV technology will be useful for large scale project assessment.
\end{abstract}

\section{Introduction}

The module temperature $\left(T_{m}\right)$ of the solar photovoltaic (PV) is more affects to the module efficiency and output power of large solar plant system. This could be because of this module temperature that affects, the performance of PV system will automatically degrades.

For assess the feasibility of any installation, the energy produce from PV array is most applicable parameter. For overall energy production modelling, modules required to be observed during different seasons for the effect of atmosphere [1]. The main point of view of this paper is, to study the estimation of seasonal variation effect on a a-Si/thin film technology under Indian atmospheric conditions. In seasonal variation, the efficiency and power for a-Si/thin film technology is taken for analysis. The Indian climate is so much different than any other countries with various seasonal patterns. There are mainly three seasons in India: summer, monsoon and winter each has different effect on the spectrum.

An experimentally setup for testing the amorphous silicon/thin film technology, a weather station and CurrentVoltage (I-V) scanner for this technology is set at National Institute of Solar Energy (NISE), Gurgaon, India, coordination with Advanced Institute for development of Industrial Science and Technology (AIST), Japan and department of New and Renewable Energy (MNRE), Government of India. The photograph for a-Si/thin film technology PV test setup in Fig. 1. This PV test setup has four major components like photovoltaic array, data logger with PV analyzer and related software for communication and analysis [2].

\footnotetext{
*e-mail: anichinte@gmail.com

**e-mail: vishwesh.vyawahare@rait.ac.in

***e-mail: dhiraj.magare@ rait.ac.in
}

\section{Methodology}

The module operating temperature $\left(T_{m}\right)$ is very major parameter while estimating the efficiency and output power because it directly affects to photovoltaic module output performance. To find out the accurate coefficients, mathematical module temperature model is very essential to operate and improve performance of solar PV module for a particular site. The amorphous-silicon/thin film technology modules are very sensitive to seasonal variation, while comparing with other technologies. In below Table 1, the given mathematical module temperature model has been taken for further estimation because it gives more accurate results in case of calculated module temperature coefficients for the site.

The coefficients calculated for this module temperature mathematical model using linear regression analysis model. This analysis is the part of data analysis tool, in which Least squares method are used for given site data [3]. Based on module temperature of a-Si/thin film technology, it is easy to calculate seasonal variation using efficiency and power formula which is given in equations (1) and (2) respectively. The module temperature $\left(T_{m}\right)$ of aSi placed important role for estimation of efficiency and power. The module temperature graphs of a-Si/thin film technology for both seasons (monsoon and clear sky day) which is shown Fig. 2 and 3.

Figure 2 shows the graph of time versus module temperature of a-Si thin film technology for $12^{\text {th }}$ July (monsoon day) with time period of 10.00 am to $3.00 \mathrm{pm}$. The level of this temperature for this particular seasonal day is suddenly drop on around $12.00 \mathrm{pm}$ to $2.00 \mathrm{pm}$ noon because of cloud effects in monsoon day. At other side in Fig. 3, shows graph module temperature variations for clear sky day.

The PV module efficiency is under the standard test condition (STC) at a temperature of $25^{\circ} \mathrm{C}$. The STC magnitudes are used in the estimation and measurement of the 


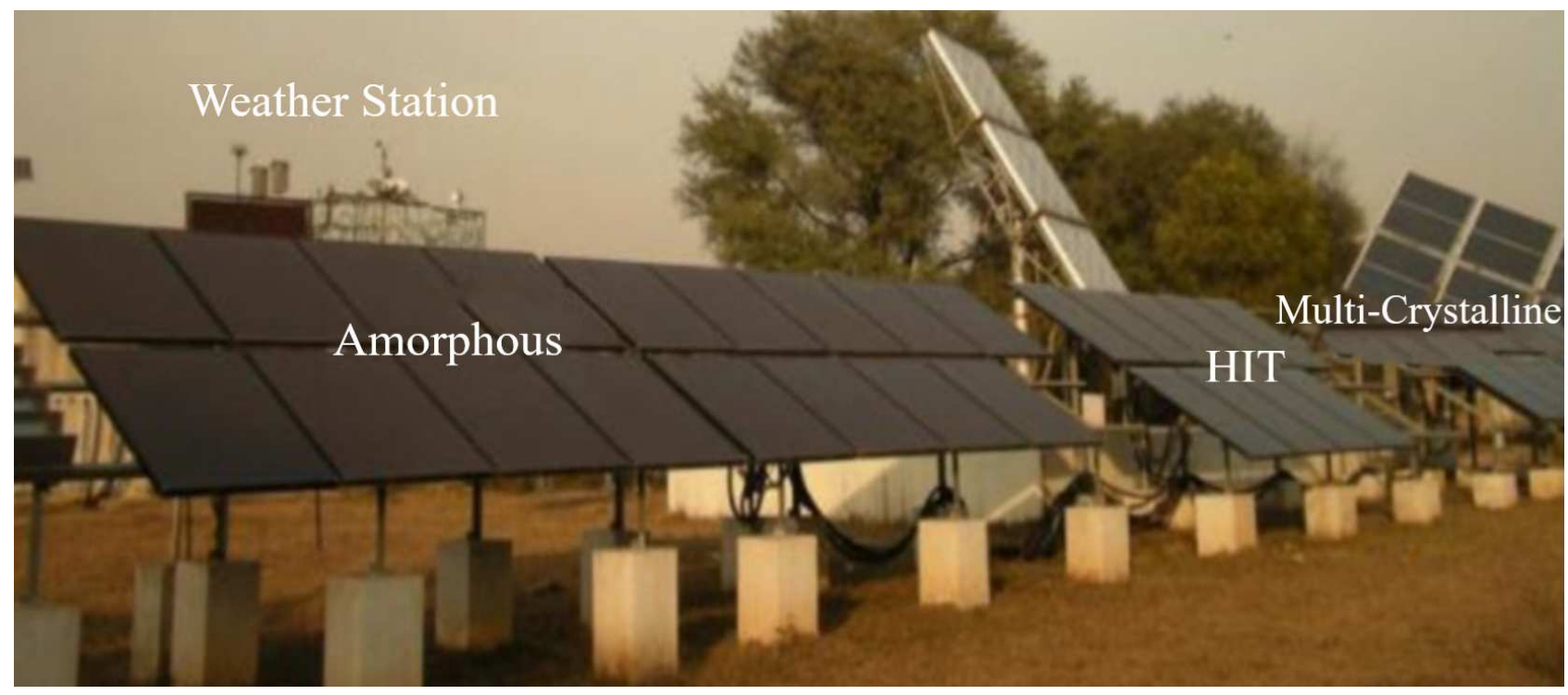

Figure 1. Outdoor test set up of a-Si/thin film PV technology module at NISE, Gurgaon, India [2].

Table 1: Calculated coefficients and their RMSE, along with coefficients of reported model [3].

\begin{tabular}{|c|c|c|c|c|c|c|c|c|c|c|c|}
\hline \multirow{2}{*}{ Model Format } & \multirow{2}{*}{ Reference } & \multirow{2}{*}{$\begin{array}{c}\text { PV } \\
\text { Technology }\end{array}$} & \multirow{2}{*}{ RMSE } & \multicolumn{4}{|c|}{ Calculated coefficients } & \multicolumn{4}{|c|}{ Reported model coefficients } \\
\hline & & & & $\mathrm{a}$ & $\mathrm{b}$ & $\mathrm{c}$ & $\mathrm{d}$ & $\mathrm{a}$ & $\mathrm{b}$ & $\mathrm{c}$ & $\mathrm{d}$ \\
\hline$\left(T_{m}=\mathrm{a}^{*} T_{a}+\mathrm{b}^{*} G_{t}+\mathrm{c}^{*} V_{w}+\mathrm{d}\right)$ & [3] & $\mathrm{a}-\mathrm{Si}$ & 4.38 & 7.2 & 0.021 & 1.07 & -1.98 & 4.3 & 0.028 & 0.94 & -1.52 \\
\hline
\end{tabular}

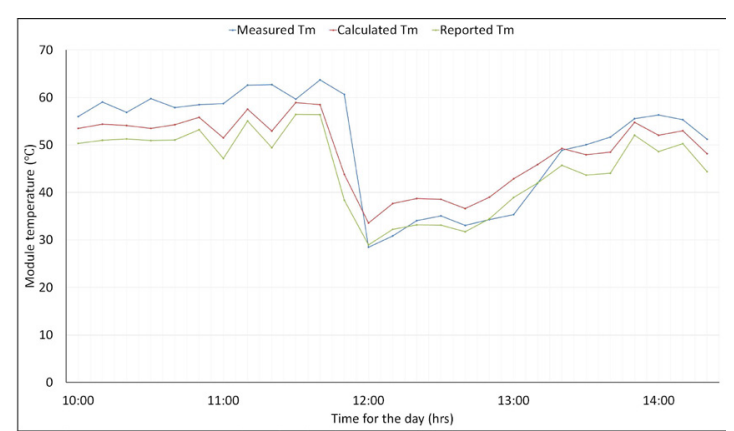

Figure 2. Module temperature graph for monsoon day $12^{\text {th }}$ July of a-Si PV technology.

PV module performance, which helps in examine the output energy of PV systems. Although, due to environmental parameters variations STC does not occur under actual field conditions. Thus, the deviation in performance of the photovoltaic module from STC may be occur [4].

The below standard equations (1) and (2) respectively, of efficiency and output power has taken for the estimation [5].

The simplify expression for electrical efficiency,

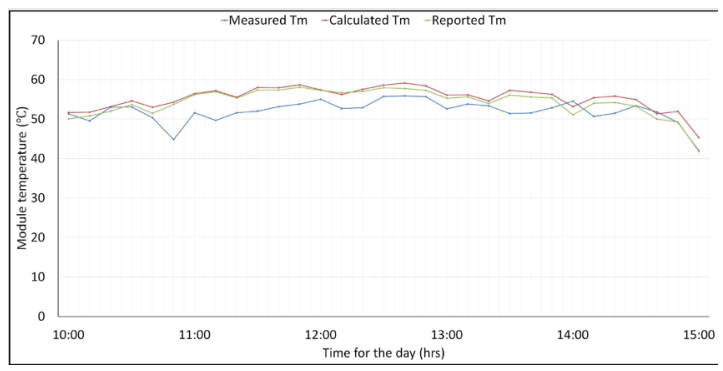

Figure 3. Module temperature graph for clear sky day $12^{\text {th }}$ Oct of a-Si PV technology.

This equation is represents the traditional linear expression for the photovoltaic electrical efficiency [6]. Where, $\eta_{c}$ is the cell efficiency, $\eta_{\text {Tref }}$ is electrical efficiency at temperature $T_{r e f}, \beta_{\text {ref }}$ is the efficiency correction coefficient for temperature $\left(C^{-1}\right)$ and $T_{c}$ is cell/module temperature. In this equations, the values of $\eta_{\text {Tref }}$, Area of module, $\beta_{\text {Tref }}$ as well as $T_{\text {ref }}$ has been taken from [4] [7]. The values of $\eta_{\text {Tref }}$ and $\beta_{\text {ref }}$ are normally given by the PV manufacturer. However, they can be obtained from laboratory tests also.

The expression for output power is,
$\eta_{c}=\eta_{T r e f}\left[1-\beta_{r e f}\left(T_{c}-T_{r e f}\right)\right]$

$$
\mathrm{P}=\eta_{c} A \mathrm{G}_{T}
$$


In this expression, $\mathrm{P}$ is the output power of solar cell/module, A is the area in $\left(\mathrm{m}^{2}\right)$ of the module, $G_{T}$ is the solar radiation and $\eta_{c}$ is the calculated efficiency of solar module.

\section{Results and Discussion}

The mathematical model ( $T_{m}=\mathrm{a}^{*} T_{a}+\mathrm{b}^{*} G_{t}+\mathrm{c}^{*} V_{w}+\mathrm{d}$ ) from Table 1 of module temperature for a-Si/thin film technology has been used for the estimation of efficiency is listed in the Table 2.

The calculated efficiency of a-Si/thin film technology for monsoon day and clear sky day and their (\%) difference which is taken between calculated average and measured average efficiency in (\%) is shown in Table 2. The estimation and analysis, the calculated average and measured average efficiency for $12^{\text {th }}$ July is $6.962 \%$ and $6.993 \%$ respectively; for $12^{\text {th }}$ Oct is $7.091 \%$ and $7.026 \%$ obtained respectively. The $(\%)$ deviation in average calculated and measured power of a-Si/thin film technology for monsoon day and clear sky day and their \% difference is shown in Table 3. The estimation and analysis, the (\%) deviation in average calculated power and average measured power for $12^{\text {th }}$ July is 71.686 and 72.832 respectively; for $12^{\text {th }}$ Oct is 18.426 and 18.413 obtained respectively. The output efficiency graphs of monsoon day and clear sky day which is shown in Fig. 4 and Fig. 5 respectively. Then the output power graphs of a-Si/thin film technology for monsoon day and clear sky day which is shown in Fig. 6 and Fig. 7.

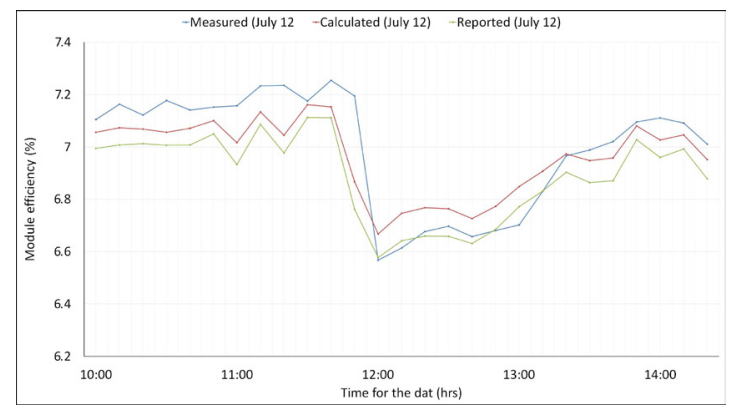

Figure 4. Efficiency for monsoon day, $12^{\text {th }}$ July of a-Si PV technology.

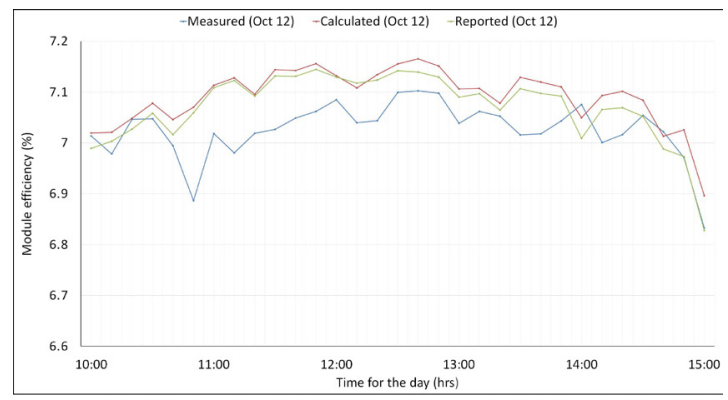

Figure 5. Efficiency for clear sky day, $12^{\text {th }}$ Oct of a-Si PV technology.
Figure 4 shows the graph of time versus module efficiency of a-Si thin film technology for $12^{\text {th }}$ July (monsoon day) with time period of 10.00 am to $3.00 \mathrm{pm}$. The level of this efficiency for this particular seasonal day is suddenly drop on around $11.00 \mathrm{pm}$ to $12.00 \mathrm{pm}$ noon, because of cloud effects in monsoon day. At other side in Fig. 5, there is efficiency graph respect to sunny hours, because of the solar panel absorb more radiation in this season.

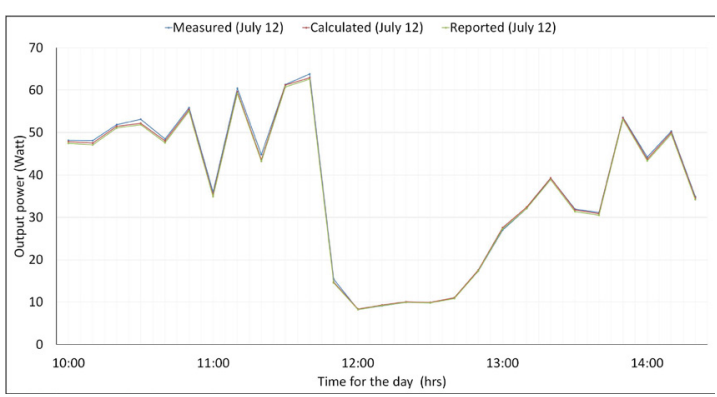

Figure 6. Output power for monsoon day, $12^{\text {th }}$ July of a-Si PV technology.

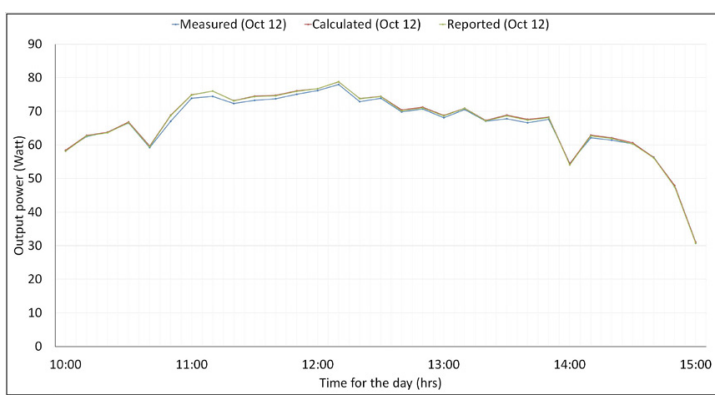

Figure 7. Output power for clear sky day, $12^{\text {th }}$ Oct of a-Si PV technology.

Figure 6 shows the graph of time versus output power of a-Si thin film technology for $12^{\text {th }}$ July (monsoon day) with time period of $10.00 \mathrm{am}$ to $3.00 \mathrm{pm}$. The level of this power for this particular seasonal day is suddenly drop on around $12.00 \mathrm{pm}$ to $2.00 \mathrm{pm}$ noon because of its dropping efficiency and global irradiance $\left(G_{t}\right)$. At other side in Fig. 7 shows, obtained power in this seasonal day.

The effect of seasonal variation of a-Si/thin film technology is shown in Fig. 8 and Fig. 9 for efficiency as well as output power respectively for the given site. The amorphous-silicon/thin film technology PV modules are very sensitive to seasonal variations as compared to module operating temperature. This gives the information about variations in three seasons. The graph plotted for particular representative day of each season, efficiency and output power is shown in Fig. 8 and Fig. 9.

\section{Conclusions}

This paper presents the relative seasonal effects on Amorphous-Silicon/thin film technology module under Indian environment. In addition, it has been successfully 
Table 2: Calculated photovoltaic module efficiency for a-Si/thin film technology module.

\begin{tabular}{|c|c|c|c|c|c|c|c|c|}
\hline Sr. No. & $\begin{array}{c}\text { PV } \\
\text { technology }\end{array}$ & $\begin{array}{c}\text { Area of } \\
\text { module in }\left(\mathrm{m}^{2}\right)\end{array}$ & Date & $\begin{array}{l}\text { Calculated avg. } \\
\text { efficiency in \% }\end{array}$ & $\begin{array}{l}\text { Measured avg. } \\
\text { efficiency in \% }\end{array}$ & $\beta_{r e f}$ in $\%$ & $\eta_{\text {Tref }}$ in $\%$ & $\begin{array}{l}\% \text { Diff. between calculated } \\
\text { and measured Efficiency }\end{array}$ \\
\hline 1 & & 1.15 & 12 July & 6.962 & 6.993 & 0.30 & 6.5 & 0.031 \\
\hline 2 & & 1.15 & $12 \mathrm{Oct}$ & 7.091 & 7.026 & 0.30 & 6.5 & 0.065 \\
\hline
\end{tabular}

Table 3: Calculated photovoltaic module power for a-Si/thin film technology module.

\begin{tabular}{|c|c|c|c|c|c|c|c|c|}
\hline Sr. No. & $\begin{array}{c}\text { PV } \\
\text { technology }\end{array}$ & $\begin{array}{l}\text { Area of } \\
\text { module in }\left(\mathrm{m}^{2}\right)\end{array}$ & Date & $\begin{array}{l}\text { \% Deviation in avg. } \\
\text { calculated power }\end{array}$ & $\begin{array}{l}\text { \% Deviation in avg. } \\
\text { measured power }\end{array}$ & $\beta_{r e f}$ in $\%$ & $\eta_{\text {Tref }}$ in $\%$ & $\begin{array}{c}\% \text { Diff. between calculated } \\
\text { and measured power }\end{array}$ \\
\hline 1 & & 1.15 & 12 July & 71.686 & 72.823 & 0.30 & 6.5 & 1.137 \\
\hline 2 & & 1.15 & $12 \mathrm{Oct}$ & 18.426 & 18.413 & 0.30 & 6.5 & 0.013 \\
\hline
\end{tabular}

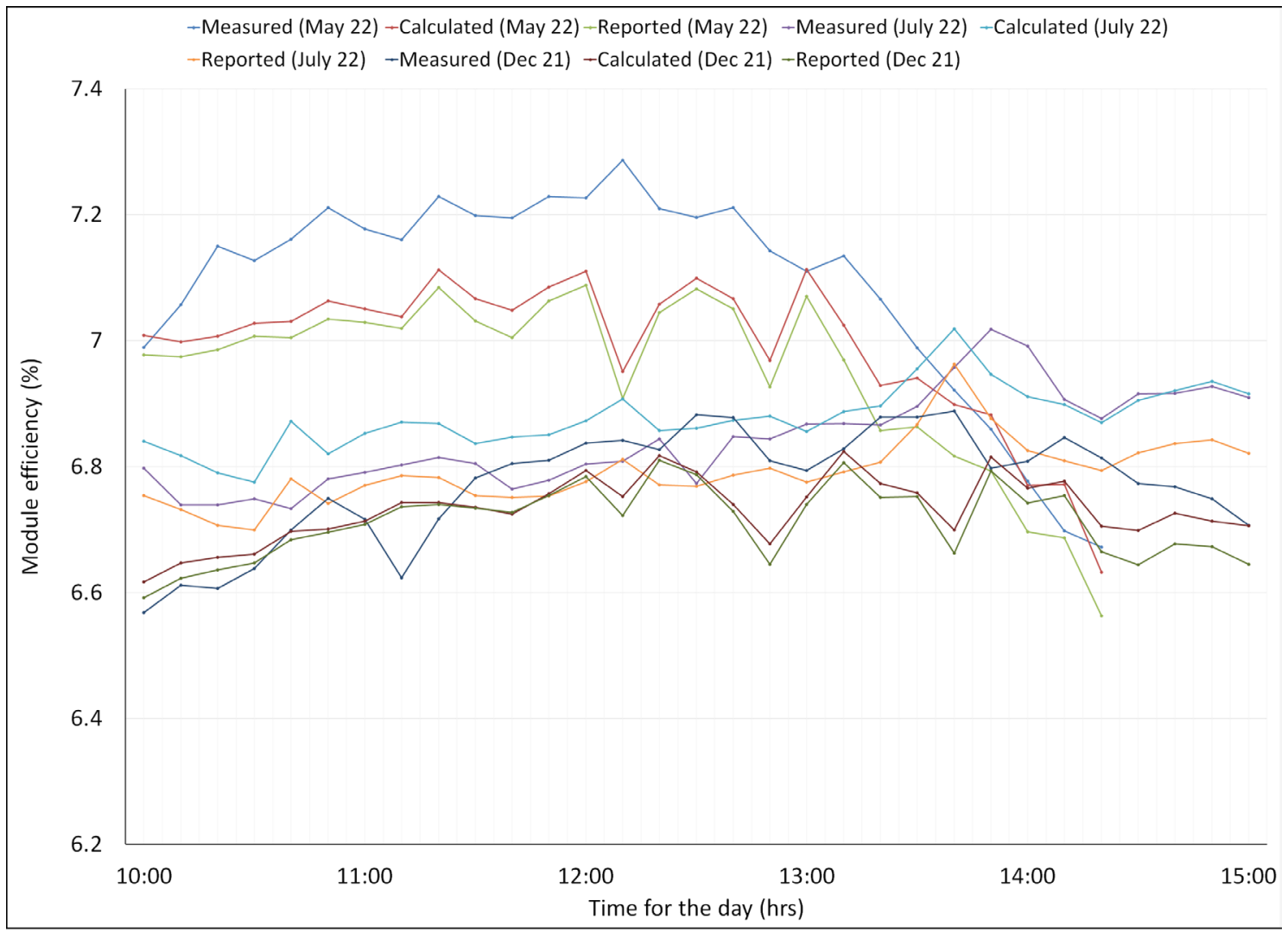

Figure 8. Seasonal module efficiency variation for Amorphous-Silicon PV technology.

estimates the efficiency and output power of Amorphous$\mathrm{Si}$ /thin film technology for National Institute of Solar Energy (NISE), Gurgaon, India. It has been observed from analysis that a-Si/thin film technology is sensitive to variation in season during all seasonal days. It is happened due to strong spectral effects, that affect performance of a-Si technology. The (\%) difference for calculated and measured of a-Si/thin film technology for monsoon and clear sky day in efficiency is $0.031 \%$ and $0.065 \%$ respectively, while (\%) difference in output power are $1.137 \%$ and $0.013 \%$ respectively.

\section{Acknowledgment}

The authors would like to thank Advanced Industrial Science and Technology (AIST), Japan.

Nomenclature

$\mathrm{a}=$ ambient temperature coefficient

$\mathrm{b}=$ irradiance coefficient, $W / \mathrm{m}^{2}$

$\mathrm{c}=$ wind speed coefficient, $\mathrm{m} / \mathrm{s}$

$\mathrm{d}=$ intercept

$T_{c} / T_{m}=$ cell or module temperature, ${ }^{\circ} \mathrm{C}$

$G_{t}=$ irradiance at tilted plane, $W / \mathrm{m}^{2}$

$T_{a}=$ ambient temperature, ${ }^{\circ} \mathrm{C}$ 


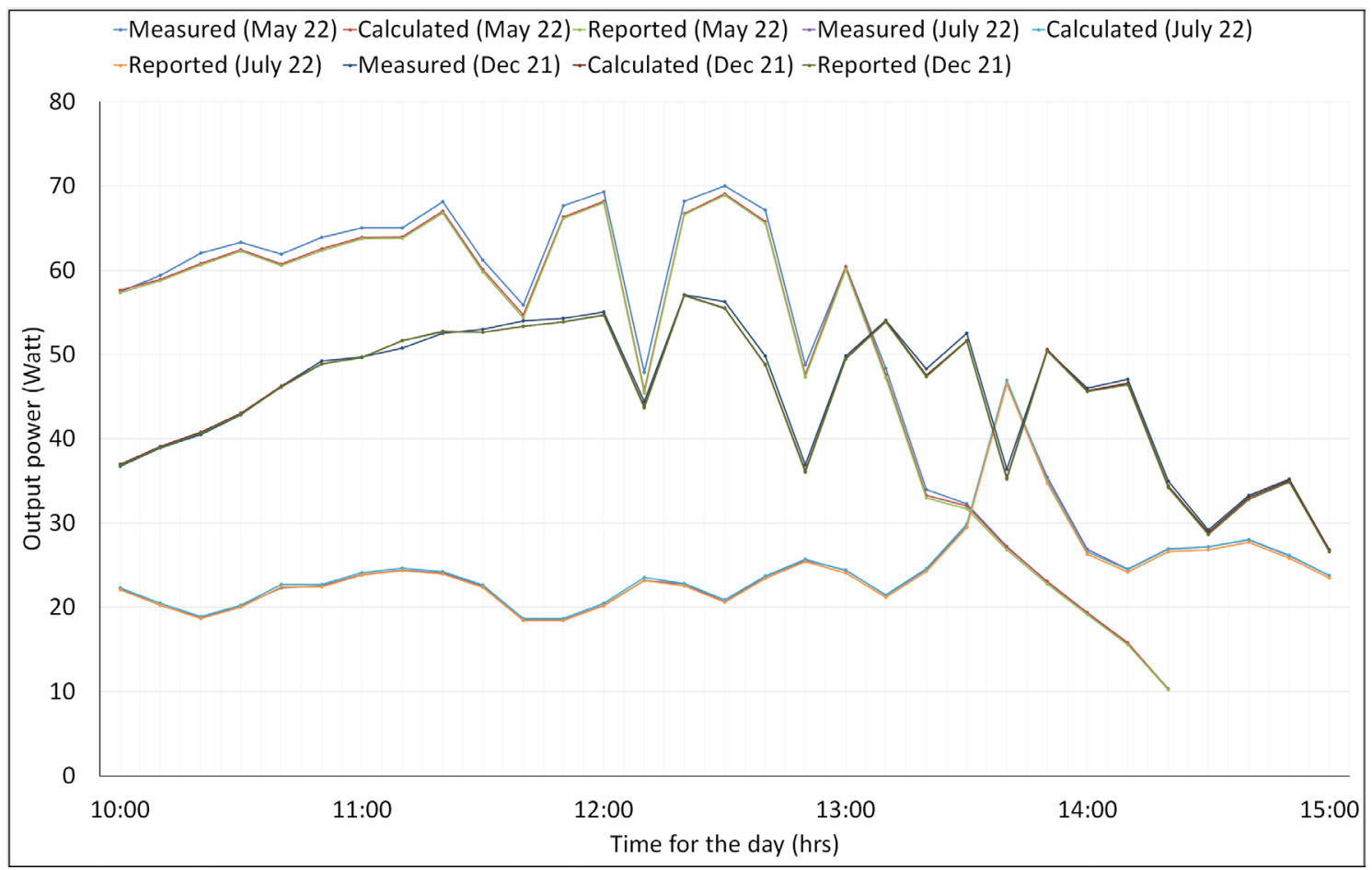

Figure 9. Seasonal module output power variation for Amorphous-Silicon PV technology.

$V_{w}=$ wind speed, $\mathrm{m} / \mathrm{s}$

$T_{\text {ref }}=$ temperature at reference condition, ${ }^{\circ} \mathrm{C}$

Greek Symbols

$\eta_{c}=$ cell or module efficiency

$\eta_{\text {Tref }}=$ electrical efficiency for temperature $T_{\text {ref }}$

$\beta_{\text {ref }}=$ Temperature coefficient for correction of efficiency $\left(C^{-1}\right)$

\section{References}

[1] Magare, D. B., Sastry, O. S., Gupta, R., Betts, T. R., Gottschalg, R., Kumar, A., ... Singh, Y. K. "Effect of seasonal spectral variations on performance of three different photovoltaic technologies in India." International Journal of Energy and Environmental Engineering, vol. 7(1), 93-103.(2015). doi:10.1007/s40095-0150190-0.

[2] Magare, D., Sastry, O. S., Gupta, R., Kumar, A., and Sinha, A., "Data Logging Strategy of Photovoltaic (PV) Module Test Beds," 27 $7^{\text {th }}$ European Photovoltaic Solar Energy Conference (EU PVSEC), Frankfurt, Germany, Sept. 24-28, pp. 3259-3262, (2012).

[3] Nichinte, A. S., Vyawahare, V. A., Magare, D. B., (2020)."Estimation and Comparison of Module Tem- perature Model Coefficient for Different PV Technology Module." $3^{\text {rd }}$ International Conference on Communication System, Computing and IT Application CSCITA (Accepted), (2020).

[4] Magare, D., Sastry, O., Gupta, R., Mohammed, H., Bora, B., \& Singh, Y. "Estimation of operating condition frequency distribution and power prediction by extending application of IEC 61853-1 standard for different technology photovoltaic modules." Journal of Renewable and Sustainable Energy, vol. 10(3),(2018). 033507. doi:10.1063/1.5023084

[5] Skoplaki, E., Boudouvis, A. G., \& Palyvos, J. A. "A simple correlation for the operating temperature of photovoltaic modules of arbitrary mounting." Solar Energy Materials and Solar Cells, vol. 92(11), 1393-1402, (2008). doi:10.1016/j.solmat.2008.05.016

[6] Evans, D.L., Florschuetz, L.W., "Cost studies on terrestrial photovoltaic power systems with sunlight concentration." Solar Energy vol. 19, 255-262, 1977.

[7] Skoplaki, E., \& Palyvos, J. A. "Operating temperature of photovoltaic modules: A survey of pertinent correlations." Renewable Energy, vol. 34(1), 23-29, (2009). doi:10.1016/j.renene.2008.04.009 